\title{
Superfical Keratectomy, Limbal Autotransplantation and Amniotic Membrane Transplantation in the Treatment of Severe Chemical Burns of the Eye
}

\author{
I. KOZÁK ${ }^{1}$, A. TRBOLOVÁ ${ }^{2}$, Z. ŠEVČÍKOVÁ ${ }^{2}$, T. JUHÁS ${ }^{1}$, V. LEDECKÝ ${ }^{2}$ \\ ${ }^{1}$ Department of Ophthalmology, P. J. Šafárik Medical School, Košice \\ ${ }^{2}$ University of Veterinary Medicine, Košice, Slovak Republic
}

Received July 4, 2001

Accepted February 13, 2002

\begin{abstract}
Kozák, I., A. Trbolová, Z. Ševčíková, T. Juhás, V. Ledecký: Superficial Keratectomy, Limbal Autotransplantation and Amniotic Membrane Transplantation in the Treatment of Severe Chemical Burns of the Eye. Acta Vet. Brno 2002, 71: 85-91.

Alkali burns are the most serious of chemical injuries of the anterior segment of the eye. Their treatment is aimed at preservation and/or restoring limbal stem cells and reconstruction of the ocular surface. Autologous limbal transplantation is used in management of damaged limbal stem cells and amniotic membrane transplantation in reconstruction of the burnt ocular surface.

The aim of this study was to clinically and histopathologically evaluate treatment of severe chemical eye injuries. Limbal autograft transplantation and transplantation of amniotic membrane were combined with superficial lamellar keratectomy. Fifteen New Zealand white male rabbits were used in the experiment. General anaesthesia was induced before $2.5 \mathrm{~N} \mathrm{NaOH}$ solution was applied to one eye of each animal. The surgery of injured eye consisted of following steps: after keratectomy of necrotic cornea limbal graft from the contralateral eye was transferred on the injured eye and covered by amniotic membrane which was attached 5-7 $\mathrm{mm}$ from the limbus. In the post-operative period Infectoflam ${ }^{\circledR}$ eye drops (Novartis) were applied 4 times daily for 4-6 weeks. Clinical evaluation was done regularly at 2 and 4 weeks and 4 and 9 months after surgery. We evaluated corneal edema, vascularization, erosion, conjunctival hyperemia, limbal ischemia, blepharospasm, ocular discharge, tear film stability and symblepharon formation.

Two eyes spontaneously perforated at the end of the first month. Corneal edema was most intense at 4 weeks and improved at the end of follow-up in 8 eyes $(62 \%)$. Vascularization was most prominent at 4 weeks in all cases and after 9 months was local in 5 eyes (38\%) and diffuse in 3 eyes $(22 \%)$. Complete re-epithelization was achieved in 9 eyes $(68 \%)$. Conjunctival hyperemia was present in all eyes at 2 weeks and in 2 eyes $(15 \%)$ at 9 months. Limbal ischemia was present in all eyes at 2 weeks and in 5 eyes $(38 \%)$ at the end of follow-up period. Blepharospasm was present in 2 eyes $(15 \%)$ at 4 months and disappeared at the last control. Purulent discharge was most intense at 2 weeks ( 9 eyes - 69\%), after 9 months we noticed only increased watering in 2 eyes $(15 \%)$. Symblepharon was initially seen in 5 eyes (38\%) and was noticed in 3 eyes (22\%) at the end of follow-up period.

Our results show that amniotic membrane transplantation after superficial keratectomy combined with limbal autograft transplantation after severe alkali burn significantly contributes to reparative process of the ocular surface.
\end{abstract}

Chemical burns, experiment, limbal autotransplantation, amniotic membrane transplantation

The integrity of the ocular surface is kept by corneal, limbal and conjunctival epithelia together with the presence of tear film. The proper function of these structures represents a universal protective mechanism of the anterior segment of the eye. When these structures and their functions are altered, ocular surface reconstruction becomes problematic.

In alkali burns, the most serious chemical injuries, saponification of fatty acids in cell membranes occurs which enhances penetration of the noxious substance to deeper layers of the anterior segment of the eye. The most important prognostic factors in clinical evaluation of the chemical eye injuries is assessment of the corneal transparency and the status of the limbal stem cells. Based on these criteria chemical injuries are classified into 4 grades

Address for correspondence:

MUDr. Igor Kozák

Dept. of Ophthalmology

Tr. SNP 1, 04011 Košice, Slovak Republic
Phone: +421556403777

Fax: +421 556429993

E-mail: 1kozak_2000@yahoo.com 
(Roper-Hall) wherein grade 3 represents subtotal and grade 4 total loss of limbal stem cells along with severe opacification of the cornea (McCulley 1987).

The loss of limbal stem cells results in recurrent epithelial defects with tear film abnormalities, vascularization and conjunctivalization of the cornea and sterile ulceration with possible spontaneous corneal perforation (Chen et al. 1991). Conjunctivalization of the cornea is the presence of conjunctiva-like epithelium containing goblet cells on the corneal surface not normally present on the cornea. In the absence of limbal stem cells conjunctivalization results in neovascularization whereas the partial presence of limbal stem cells causes so-called conjunctival transdifferentiation - morphologic change to corneal epithelium without goblet cells (Kruse et al. 1990).

Management of severe chemical injuries should, therefore, be focused on preservation and/or renewal of the limbal stem cells and ocular surface reconstruction. A successful option in the treatment of damaged or absent limbal stem cells has been limbal autograft transplantation (LAT) from the contralateral eye (Tsubota et al. 1999). This method of limbal cells repopulation has been suggested first by Ken y on et al. (1989).

Amniotic membrane transplantation (AMT) is used for reconstruction of the burnt ocular surface. It is a procedure complementary to LAT and in severe injuries each procedure is done simultaneously. AMT was first done by De Rotth in 1940 in a patient with symblepharon. Early AMT facilitates epithelization and reduces inflammation, vascularization, and scarring. However, AMT cannot prevent the loss or repopulate limbal stem cells (Meller et al. 2000).

The aim of this study was to clinically and histopathologically evaluate treatment of severe chemical eye injuries. Limbal autograft transplantation and transplantation of amniotic membrane were combined with superficial lamellar keratectomy in order to remove necrotic corneal tissue.

\section{Materials and Methods}

The experiments conformed to the regulations of Ethic Committee of the University of Veterinary Medicine in Košice, Slovakia. Fifteen New Zealand white male rabbits aged 8 months and weighing $2.5-3.0 \mathrm{~kg}$ were used in the experiment. Before enrollment to the study all rabbits were ophthalmologically examined (inspection, biomicroscopic examination of the anterior segment, ophthalmoscopy of the posterior segment) and if an abnormality was found the rabbit was excluded.

General anesthesia was induced before the caustic $2.5 \mathrm{~N} \mathrm{NaOH}$ solution was applied to one eye of each rabbit using a swab (Plate IX, Fig. 1). For premedication $0.05 \mathrm{mg} \cdot \mathrm{kg}^{-1}$ atropin i.m. (Atropin Spofa inj. $0.5 \mathrm{mg} \cdot \mathrm{ml}^{-1}$, Biotika) was administered and after $15 \mathrm{~min}$ we applied $5 \mathrm{mg} \cdot \mathrm{kg}^{-1}$ xylazin (Rometar $2 \%$, Spofa) with $40 \mathrm{mg}^{-\mathrm{kg}^{-1}}$ ketamin (Narkamon $5 \%$, Spofa) within one syringe.

$\mathrm{NaOH}$ was left on the ocular surface for $60 \mathrm{~s}$ and then the burnt area was extensively washed by saline continually for 5 min. Surgery was done on day 3 after chemical burn.

Amniotic membrane preparation

Amniotic membrane with attached placenta was obtained at caesarean section of a dairy cow. The tissue was obtained only from clinically healthy cows. Under sterile conditions the amniotic membrane with the placenta were washed in saline. Subsequently the amniotic membrane was detached from the chorion and other decidual tissue by blunt preparation and cut to pieces $5 \times 5 \mathrm{~cm}$. The tissue was placed in a solution containing $50 \mu \mathrm{g} \cdot \mathrm{ml}^{-1}$ penicillin, $50 \mu \mathrm{g} \cdot \mathrm{ml}^{-1}$ streptomycin and $100 \mu \mathrm{g} \cdot \mathrm{ml}^{-1}$ neomycin. The amniotic membranes were placed in the refrigerator at a temperature of $2^{\circ} \mathrm{C}$ and used the following day.

\section{Surgical procedure}

Injury to the eye and harvesting of tissue were done under the same anesthesia. A limbal graft wide approximately $2.5-3 \mathrm{~mm}$ was obtained from non-injured contralateral eye from 11. to $2 \mathrm{o}$ 'clock position. The defect in the donor eye was sutured by non-resorbable suture Ethilon 10.0 with microfilament polyamid fiber and "micro-point" atraumatic needle $6 \mathrm{~mm}$ long with 38 curvature. Interrupted sutures were used (Plate IX, Fig. 2). Harvested tissue was kept in sterile balanced salt solution until the moment of transplantation.

The chemically injured eye was first treated by superficial keratectomy with subsequent excision of necrotic conjunctiva. The limbal graft was placed on the corresponding site (11 to 2.o'clock) of the injured eye and sutured by interrupted Ethilon 10.0 sutures. Amniotic membrane was taken and placed on the cornea so that it could be sutured 5-7 mm from the limbus circumferentially. Single Vicryl 8.0 sutures were used (Plate X, Fig. 3). 
Postoperative treatment

In the post-operative period rabbits received Infectoflam ${ }^{\circledR}$ (gentamycin + fluorometholone, Novartis) eye drops 4 times daily to both eyes for 2 weeks. The injured eye was treated for additional 4 weeks. At 6 weeks postoperatively ascorbate (ascorbic acid: BSS $=1: 1$ ) was topically applied 2x daily into the injured eye.

Histopathological exam

Tissue samples from the injured and grafted eye were taken for histopatologic examination 9 month after surgery. These were fixed within $3 \mathrm{~min}$ in $10 \%$ neutral formalin and processed by embedding in paraffin. Sections of 5-6 $\mu \mathrm{m}$ width were stained with hematoxylin/eosin.

\section{Statistics}

For statistical evaluation, $\chi^{2}$ test with Fischer-Yates correction was used.

\section{Results}

Every rabbit was carefully followed-up during 9 months after surgery. The first clinical report was done after 2 and 4 weeks and after 4 and 9 months after surgery. Two eyes within the first post-operative month spontaneously perforated after formation of sterile ulceration and were excluded from the group.

Corneal edema, vascularization and erosion, presence of discharge and blepharospasm, degree of conjunctival hyperemia and limbal ischemia, tear film stability and formation of symblepharon were evaluated (Tables 1 - 8). After the follow-up period rabbits were euthanised and corneas with adjacent limbal area were histologically examined.

Corneal edema (Table 1) was most prominent 4 weeks after surgery when 7 eyes (54\%) deteriorated to moderate/severe edema as compared to the second post-operative week. Corneal edema later improved and 8 eyes $(62 \%)$ improved after a period of 9 months.

Vascularization (Table 2) occurred throughout the whole follow-up period. Its incidence, similarly to corneal edema, increased in week 4 after surgery in 3 eyes (22\%) as compared to second week after surgery. At the end of follow-up period local superficial vascularization was present in the area adjacent to limbal autograft in 5 eyes $(38 \%)$ and in 3 eyes $(22 \%)$ vascularization was diffuse superficial.

Table 1

Occurrence of edema

\begin{tabular}{|c|c|c|c|c|}
\hline Grade & 2. week & 4. week & 4. month & 9. month \\
\hline 0 & 0 & 0 & 0 & 4 \\
\hline 1 & 7 & 0 & 4 & 4 \\
\hline 2 & 6 & 8 & 7 & 5 \\
\hline 3 & 0 & 5 & 2 & 0 \\
\hline
\end{tabular}

0 - no edema

1 - mild subepithelial edema

2 - moderate stromal edema

3 - severe edema with loss of corneal transparency

Table 2

Corneal vascularization

\begin{tabular}{|c|c|c|c|c|}
\hline Grade & 2. week & 4. week & 4. month & 9. month \\
\hline 0 & 3 & 0 & 3 & 5 \\
\hline 1 & 5 & 9 & 7 & 5 \\
\hline 2 & 5 & 4 & 3 & 3 \\
\hline 3 & 0 & 0 & 0 & 0 \\
\hline
\end{tabular}

0 - no vascularization

1 - superficial focal vascularization

2 - superficial diffuse vascularization

3 - deep vascularization 
Clinical evaluation of corneal erosion (Table 3) and tear film stability showed that 9 eyes $(68 \%)$ were completely re-epithelized at the end of 9 months. Three eyes $(22 \%)$ showed erosion of $20 \%$ of corneal surface and one eye with $50 \%$ of corneal surface with positive fluorescein test.

Mild conjunctival hyperemia (Table 4) was present in all eyes at the 2. post-operative week in 10 eyes $(78 \%)$ and more intense in 3 eyes $(22 \%)$. This gradually improved and after 9 months mild hyperemia persisted only in 2 eyes $(15 \%)$.

Table 3

Corneal erosion

\begin{tabular}{|c|c|c|c|c|}
\hline Grade & 2. week & 4. week & 4. month & 9. month \\
\hline 0 & 9 & 4 & 7 & 9 \\
\hline 1 & 4 & 7 & 3 & 3 \\
\hline 2 & 0 & 2 & 1 & 1 \\
\hline 3 & 0 & 0 & 1 & 0 \\
\hline 4 & 0 & 0 & 1 & 0 \\
\hline
\end{tabular}

$0-$ no erosion

1 - damage to $20 \%$ of epithelium

2 - damage to $50 \%$ of epithelium

3 - damage to $80 \%$ of epithelium

4 - corneal ulcer

Table 4

Conjunctival hyperemia

\begin{tabular}{|c|c|c|c|c|}
\hline Grade & 2. week & 4. week & 4. month & 9. month \\
\hline 0 & 0 & 5 & 7 & 11 \\
\hline 1 & 10 & 6 & 6 & 2 \\
\hline 2 & 3 & 2 & 0 & 0 \\
\hline 3 & 0 & 0 & 0 & 0 \\
\hline
\end{tabular}

0 - no hyperemia

1 - mild conjunctival hyperemia

2 - moderate conjunctival hyperemia

3 - severe conjunctival hyperemia

Table 5

Limbal ischemia

\begin{tabular}{|c|c|c|c|c|}
\hline Grade & 2.week & 4.week & 4. month & 9. month \\
\hline 0 & 0 & 2 & 4 & 8 \\
\hline 1 & 7 & 8 & 6 & 4 \\
\hline 2 & 5 & 3 & 3 & 1 \\
\hline 3 & 1 & 0 & 0 & 0 \\
\hline
\end{tabular}

0 - no limbal ischemia

1 - ischemia of $1 / 3$ limbal circumference

2 - ischemia of $1 / 3-1 / 2$ limbal circumference

3 - total limbal ischemia

Limbal ischemia (Table 5), assessed by biomicroscopy, persisted in all rabbits in the 2 . post-operative week. Ischemic limbus slowly revascularized from the area of transplant circumferentially. At the last examination 5 eyes $(38 \%)$ showed residual limbal ischaemia.

Blepharospasm (Table 6) persisted 4 months in 2 eyes $(22 \%)$ but disappeared at the end 
Table 6

Blepharospasm

\begin{tabular}{|c|c|c|c|c|}
\hline Occurrence & 2. week & 4. week & 4. month & 9. month \\
\hline Present & 8 & 8 & 2 & 0 \\
\hline Absent & 5 & 5 & 11 & 13 \\
\hline
\end{tabular}

Table 7

Discharge

\begin{tabular}{|c|c|c|c|c|}
\hline Occurrence & 2. week & 4. week & 4. month & 9. month \\
\hline Present & 9 & 8 & 4 & 2 \\
\hline Absent & 4 & 5 & 9 & 11 \\
\hline
\end{tabular}

Table 8

Symblepharon

\begin{tabular}{|c|c|c|c|c|}
\hline Occurrence & 2. week & 4. week & 4. month & 9. month \\
\hline Present & 2 & 5 & 4 & 3 \\
\hline Absent & 11 & 8 & 9 & 10 \\
\hline
\end{tabular}

of follow-up. The incidence of blepharospasm decreased significantly $(p<0.05)$ between the first ( 2 weeks) and last ( 9 months) postoperative examinations, and so did the incidence of inflammatory discharge $(p<0.05)$. There was no statistical significance in the incidence of symblepharon formation between the two exams $(p<0.05)$.

Purulent discharge (Table 7) was most intense 2 weeks after surgery in 9 cases $(69 \%)$. After 9 months the discharge was replaced by increased tearing in 2 cases $(15 \%)$. Symblepharon (Table 8) despite continuous breaking was present in 5 eyes (38\%) 4 weeks after surgery and after 9 months was seen in 3 eyes (22\%). Typical finding 2 weeks after surgery was upper eyelid scarring. We observed this finding in 7 eyes $(54 \%)$ but the changes did not interfere with eyelid function.

Histopathology in all cases revealed complete re-epithelization of corneal surface, subepithelial fibroplasia corresponding to time ( 9 months) after surgery and subepithelial round cell infiltration with neovascularization which progressed to mature fibrose tissue (Plate X, Fig. 4; Plate XI, Figs 5 and 6).

\section{Discussion}

Chemical injury is a severe trauma to the ocular surface. Apart from epithelial damage to the cornea and conjunctiva extensive alkali burns cause damage to the limbus which is the source of stem cells for corneal re-epithelization. One of the treatment options for reconstruction of the damaged ocular surface is amniotic membrane transplantation with limbal autograft transplantation from non-injured contralateral eye.

In partial limbal deficiency, AMT alone improves local finding and assists in ocular surface wound healing. In total limbal stem cells deficiency AMT must be accompanied by LAT from the contralateral eye provided it is not equally damaged (Tseng et al. 1998).

The present work evaluates clinical and histopathologic findings after surgical reconstruction with AMT and LAT of the anterior segment after severe (grade IV.) alkali burn with total loss of limbal stem cells in 15 rabbit eyes. The reconstructive procedure included superficial keratectomy, limbal autograft transplantation and transplantation of amniotic membrane. Topical post-operative therapy included Infectoflam ${ }^{\circledR}$ (gentamycin + fluorometholone, Novartis) and ascorbate.

Amniotic membrane spontaneously sloughed off after approximately two weeks from the 
transplantation. Immunosuppressive therapy was not used as the limbal transplant was an autograft and AMT itself prevents limbal rejection (Tseng et al. 1998).

Two eyes spontaneously perforated after sterile corneal ulceration at the end of the first month. This period was characterized by the highest incidence of erosions which correlates with observations of Wagoner (1997) and Kruse et al. (1999). In other eyes reparative processes prevailed. Corneal edema was present in some eyes 4 months after surgery. Five eyes revealed moderate edema and 4 eyes slight epithelial edema with anterior stroma involvement at the last control. Edema was present in all eyes with neovascularization and in two eyes healed by local corneal opacity.

Neovascularization, mainly superficial, was observed approximately after 4 months postoperatively and persisted until the last control. It was observed most frequently in cornea adjacent to the limbal transplant which has not been described previously. We also observed that the stroma does not ulcerate in the presence of fibrovascular pannus. The reason for this is the production of collagenase inhibitors from newly-formed vessels (Berman 1993; Cooper et al. 1985). Four eyes healed with smooth corneal surface but local corneal opacity. These opacities were stromal changes in the cornea caused by alkali damage. AMT alone does not remove corneal opacities (Kru se et al. 1999). We noticed a gradual renewal of limbal vascularity after limbal transplant attachment 1 month after surgery. Limbal transplant rejection was not observed.

Conjunctival hyperemia was present between 2 to 4 weeks after the procedure. After this time it disappeared in all but 2 eyes probably due to post-operative anti-inflammatory therapy. Shortly after surgery significant blepharospasm was observed which disappeared after 4 months. The same dynamics were observed with discharge assessment. The secretions were purulent only in 3 eyes including 2 eyes that spontaneously perforated. Two weeks after surgery fluorescein test revealed tear film defects in the majority of eyes. With progressive epithelial wound healing tear film stabilized except for 2 eyes.

Some eyes showed eyelid and fornix deformities with symblepharon formation 4 months after surgery. Symblephara were continuously broken down but remained in 3 eyes at 9 months. Eyelid scarring was present in almost all eyes but with no effect on eyelid function. A relatively low incidence of these late complications is mentioned in the work of Meller et al. (2000) but their group consisted of fewer subjects patients with chemical burns. Figs. 5 and 6 show post-operative healing after 4 and 9 months, respectively.

Histopathologic changes found at the end of follow-up period are characteristic of chronic process without complications. Histopathology shows good regeneration of corneal epithelium and an adequate repair of all corneal layers in 9 cases. At the same time persisting neovascularization and subepithelial round cell infiltration 9 months after surgery speak of continuing repair in deeper corneal layers.

In conclusion, our observations show that superficial keratectomy combined with limbal autotransplantation and amniotic membrane transplantation significantly contribute to the reparative processes in the treatment of severe chemical burns of the eye.

\section{Superficiálna keratektómia, limbálna autotransplantácia a transplantácia amniotickej membrány $v$ liečbe tažkých chemických poranení oka}

Alkalické poranenia predstavujú najtažšie chemické poranenia predného segmentu oka. Ich liečba je zameraná na uchovanie resp. obnovu limbálnych kmeňových buniek a rekonštrukciu povrchu oka. V liečbe poškodenia limbálnych kmeňových buniek sa využiva autológna limbálna transplantácia a na rekonštrukciu poleptaného povrchu oka transplantácia amniotickej membrány.

Cielom tejto štúdie bolo klinicky a histopatologicky zhodnotit liečbu tažkých chemických poranení oka. Limbálna autológna transplantácia a transplantácia amniotickej membrány 
boli kombinované so superficiálnou lamelárnou keratektómiou. V experimente bolo použitých 15 novozélandských bielych králičích samcov a každé oko bolo leptané $2.5 \mathrm{~N}$ $\mathrm{NaOH}$. Chirurgický postup obsahoval následujúce kroky: po keratektómii nekrotickej rohovky bol prenesený limbálny lalok z kontralaterálneho oka na oko poleptané a to bolo prekryté amniotickou membránou, ktorá bola fixovaná 5-7 mm od limbu. V pooperačnom období sme králikom aplikovali očné kvapky Infectoflam ® (NOVARTIS) 4-krát denne po dobu 4-6 týždňov. Klinicky sme stav hodnotili pravidelne po 2 a 4 týždňoch a po 4 a 9 mesiacoch po výkone. Hodnotili sme edém rohovky, vaskularizáciu, eróziu, prekrvenie spojovky, limbálnu ischémiu, blepharospazmus, výtok z oka, stabilitu slzného filmu a tvorbu symblepharonu.

Dve oči spontánne perforovali ku koncu prvého mesiaca. Edém rohovky bol najintenzívnejší po 4 týždňoch a ku koncu sledovaného obdobia sa zmiernil u 8 očí (62\%). Vaskularizácia u všetkých očí bola najmohutnejšia po 4 týždňoch a po 9 mesiacoch bola lokálna u 5 očí $(38 \%)$ a difúzna u 3 očí (22\%). U 9 očí $(68 \%)$ došlo ku kompletnej reepitelizácii. Prekrvenie spojovky bolo prítomné u všetkých očí po 2 týždňoch sledovania a u 5 očí $(22 \%)$ ešte po 9 mesiacoch. Limbálnu ischémiu sme našli u všetkých očí po 2 týždňoch a u 5 očí (38\%) na konci doby sledovania. Blepharospazmus bol prítomný u 2 očí (15\%) po 4 mesiacoch a vymizol pri poslednej kontrole. Hnisavý výtok z oka bol najväčší po 2 týždňoch ( 9 očí - 69\%) a po 9 mesiacoch sme pozorovali len vodnatý sekrét u 2 očí (15\%). Symblepharon pôvodne prítomný u 5 očí (38\%) sme našli u 3 očí (22\%) na konci sledovaného obdobia.

Naše výsledky ukazujú, že transplantácia amniotickej membrány po superficiálnej keratektómii kombinovaná s limbálnou autotransplantáciou po tažkom chemickom poranení signifikantne prispieva k reparačným procesom na povrchu oka.

\section{Acknowledgement}

The authors wish to thank Robert J. Fabiny, PhD, M.D. from the Mayo Clinic Foundation in the United States for his thoughtful comments and proof-reading.

\section{References}

BERMAN, M. B. 1993: Regulation of corneal fibroblast MMP-1 collagenase secretion by plasmin. Cornea 12 : $420-432$

COOPER, T. W., EISEN, A. Z., STRICKLIN, G. P., WELGUS, H. G. 1985: Platelet derived collagenase inhibitor: characterization and subcellular localization. Proc. Natl. Acad. Sci. USA 82: 2779-2783

CHEN, J. J. Y., TSENG, S. C. G. 1991: Abnormal corneal epithelial wound healing in partial-thickness removal of limbal epithelium. Invest. Ophthalmol. Vis. Sci. 32: 2219-2232

De ROTTH, A. 1940: Plastic repair of conjunctival defects with fetal membrane. Arch. Ophthalmol.: 23: 522-525

KENYON, K. R., TSENG, S. C. G. 1989: Limbal autograft transplantation for ocular surface disorders. Ophthalmology 96: 709-723

KRUSE, F. E., CHEN, J. Y., TSAI, R. J. F., TSENG, S. C. G. 1990: Conjunctival transdifferentiation is due to the incomplete removal of limbal basal epithelium. Invest. Ophthalmol. Vis. Sci. 31: 1903-1912

KRUSE, F. E., ROHRSCHNEIDER, K., VOLCKER, H. E. 1999: Multilayer amniotic membrane transplantation for reconstruction of deep corneal ulcers. Ophthalmology 106: 1504-1510

McCULLEY, J. P. 1987: Chemical injuries. In: SMOLIN, G. and THOFT, R. A.: The Cornea: Scientific foundation and clinical practice. Boston, Little, Brown and Co. pp. 527-542

MELLER, D., PIRES, R. T. F., MACK, R. J. S., FIGUEIREDO, F., et al. 2000: Amniotic membrane transplantation for acute chemical or thermal burns. Ophthalmology 107: 980-988

TSENG, S. C. G., PRABHASAWAT, P., BARTON, K., GRAY, T., et al. 1998: Amniotic membrane transplantation with or without limbal allografts for corneal surface reconstruction in patients with limbal stem cell deficiency. Arch. Ophthalmol. 116: 431-441

TSUBOTA, K., SATAKE, Y., KAIDO, M., SHINOZAKI, A., et al. 1999: Treatment of severe ocular-surface disorders with corneal epithelial stem-cell transplantation. N. Engl. J. Med. 340: 1697-1703

WAGONER, M. D. 1997: Chemical injuries of the eye: Current concepts in pathophysiology and therapy. Surv. Ophthalmol. 41: 275-303 